Revue de droit comparé du travail et de la sécurité sociale

4 | 2017

English Electronic Edition

\title{
The Impact of the Sectoral Law on the Construction and Construction Industry on Collective Bargaining and the Right to Strike
}

Shae McCrystal

\section{(2) OpenEdition \\ 1 Journals}

Electronic version

URL: https://journals.openedition.org/rdctss/2508

DOI: $10.4000 /$ rdctss.2508

ISSN: 2262-9815

Publisher

Centre de droit comparé du travail et de la sécurité sociale

Printed version

Date of publication: 1 December 2017

Number of pages: 238-241

ISSN: $2117-4350$

Electronic reference

Shae McCrystal, "The Impact of the Sectoral Law on the Construction and Construction Industry on Collective Bargaining and the Right to Strike", Revue de droit comparé du travail et de la sécurité sociale [Online], 4 | 2017, Online since 01 November 2021, connection on 04 December 2021. URL: http:// journals.openedition.org/rdctss/2508; DOI: https://doi.org/10.4000/rdctss.2508

\section{(C) $\Theta \Theta \Theta$}

Revue de droit comparé du travail et de la sécurité sociale est mise à disposition selon les termes de la Licence Creative Commons Attribution - Pas d'Utilisation Commerciale - Pas de Modification 4.0 International. 


\title{
SHAE MCCRYSTAL
}

\author{
UNIVERSITY OF SYDNEY
}

\section{The Impact of the Sectoral LaW on the Construction AND CONSTRUCTION INDUSTRY ON COLleCtive BARgaining AND THE RIGHT TO STRIKE}

In December 2016, the federal Parliament of Australia passed the Building and Construction Industry (Improving Productivity) Act ('BCIIP Act') which provides for regulation of labour relations in the 'building and construction industry' in addition to the regulation that otherwise applies under the Fair Work Act 2009 (Cth) ('FW Act'). The BCIIP Act further restricts the right to strike for workers, limits the types of agreements that employers and unions can create, increases penalties in the industry and provides for separate enforcement and oversight in this sector.

The history behind the passage of the BCIIP Act dates back to 2005. The first specific regulation of the building industry, the Building and Construction Industry Improvement Act 2005 (Cth), was introduced by a Coalition Government. It was passed by federal Parliament in the wake of the 2003 Royal Commission into the Building and Construction Industry which had found evidence of widespread unlawful conduct in the industry and recommended the establishment of an enforcement agency to ensure compliance with the law by building industry participants. ${ }^{1}$ The 2005 Act was opposed by the Australian Labor Party (ALP) in opposition and the trade union movement. When the ALP took federal government in 2007, it passed legislation to repeal the 2005 Act while retaining a separate regulator for the industry.

The re-election of the Coalition government in 2013 saw pressure to reinstate the provisions of the 2005 Act. The government instituted another Royal Commission, this time into Trade Union Corruption, ${ }^{2}$ and introduced two Bills to reinstate the substance of the 2005 Act. Both Bills were defeated in the Senate (the upper house of federal Parliament), and the defeat of the second Bill was used as a trigger to send both houses of federal Parliament to a 'double dissolution' election. Such an election sends all members of Parliament to an election (usually only half of the Senate faces election at any one time), and permits a joint sitting of the two houses of the new Parliament to pass the legislation twice rejected by the previous Parliament.

After the double dissolution election, the Coalition government was returned with a substantially reduced majority, such that it was not clear that the proposed Bill would pass if a joint sitting of federal Parliament was held. However, through negotiations with minority parties in the Senate who hold the balance of power, the government eventually was able to negotiate passage of the 'BCIIP Act' in December 2016.

1 Cole, T, Final Report of the Royal Commission into the Building and Construction Industry, Commonwealth of Australia, Canberra, 2003.

2 Heydon, JD, Royal Commission into Trade Union Governance and Corruption: Final Report, Commonwealth of Australia, Canberra, 2015. 
The BCIIP Act applies to 'building work' (defined in $s 6$ by reference to a range of activities that take place in the industry) carried out by 'building industry participants' (defined in s 5 to include a building employer, a building employee, a building contractor, a building association or representative thereof, and a person entering into a contract with a building contractor to carry out building work). The BCIIP Act is designed to be as broad as possible, encompassing building industry participants, not just those who are employers and employees in the industry - permitting the reach of the enforcement and oversight provisions of the Act to go beyond the employment relationship.

The BCIIP Act applies to this industry in addition to the extensive regulation of labour relations more generally in Australia under the FW Act.

In respect to the regulation of collective labour relations, there are three important differences between the FW Act and the BCIIP Act. These relate to the matters in respect of which the parties can reach agreement, the right to strike and the penalties applied in respect of certain unlawful behaviour.

The FW Act regulates collective bargaining and agreement making. The Act imposes limits on the content that can be agreed upon between parties creating 'enterprise agreements' - agreements that are created and enforced under the Statute. However, the FW Act does not generally prevent industrial actors from reaching collective agreements outside the Act, where those agreements constitute contracts at common law, or operate on the basis of custom or practice within the industry.

One practice in the building and construction industry is for the creation of 'project agreements' which are 'head' agreements at a proposed project which require all contractors later engaged on the site to observe the terms of the agreement in respect of the pay and conditions of their workers in connection with work carried out on that site. Such project agreements may take the form of a formally negotiated agreement under the FW Act, or an informal contract operating outside of the FW Act. These agreements operate to ensure equal pay and conditions for all workers engaged on a project, irrespective of the contractual arrangements applying on site, and are a union security device to avoid the undercutting of collectively negotiated terms and conditions of engagement.

Such 'project agreements' are rendered unenforceable by s 59 of the BCIIP Act. It provides that an agreement entered into with respect to building employees is unenforceable if it is 'entered into with the intention of securing standard employment conditions for building employees in respect of work that they carry out at a particular building site' where not all of the 'employees are employed in a single enterprise'. This provision expressly undermines attempts by workers to shore up their terms and conditions of engagement in the context 
of building projects where the work is contracted out to a variety of sub-contractors, rather than being undertaken by a single construction company.

The second major area of difference is in relation to the right to strike. As with collective bargaining, the ability to take strike action is regulated by the FW Act, and is limited to action taken by employees in support of negotiations for a single-enterprise agreement, where a number of statutory pre-requisites have been met. ${ }^{3}$ Strike action which does not comply with these requirements is known as 'unprotected industrial action'. Such action is not expressly unlawful under the FW Act, but may be subject to injunctive relief or damages at common law, or orders to stop the action by the Fair Work Commission. A breach of a stop order is an offence.

The right to strike is further curtailed for building industry participants by s 46 of the BCIIP Act which makes all unprotected industrial action by a person subject to the Act unlawful. A person that 'organises or engages' in unprotected industrial action commits an offence. The substantial change from the FW Act, is that unprotected action is automatically a breach of the Act and a fine can issue if enforcement proceedings are taken.

The BCIIP Act also creates the novel offence of 'unlawful picketing'. Picketing connected with an industrial dispute is not per se unlawful in Australia, if the picket itself is peaceful and involves no obstruction, besetting or other breach of the criminal laws. ${ }^{4}$ However, BCIIP Act s 47 provides that a person 'must not organise or engage in an unlawful picket'. An unlawful picket is defined as action that has the purpose of preventing or restricting a person from accessing or leaving a building site; or directly prevents or restricts a person accessing or leaving a building site; or would reasonably be expected to intimidate a person accessing or leaving a building site, and which is motivated for the purpose of supporting or advancing claims in connection with the engagement of workers in the industry or the purposes of advancing industrial objectives of trade unions. This provision renders lawful protest action unlawful if done with the requisite intention, or which has the necessary effect - but only in this industry. Conduct which has the effect of hindering or preventing access to building sites is already unlawful in Australia; it is not clear that the problems in this industry over unlawful pickets required an additional step.

Finally, ss 49 - 55 of the BCIIP Act increases applicable penalties for contraventions of certain offences under the FW Act for building industry participants. The offences include breaching the prohibitions on payment in respect of periods of industrial action, and offences relating to coercion or discrimination. Through these provisions, participants in this industry have been singled out for significantly higher penalties.

The remainder of the BCIIP Act provides for the powers and functions of the Australian Building and Construction Commission (ABCC), and the Australian Building and Construction Commissioner (ABC Commissioner), which have responsibility for oversight and litigation to enforce the provisions of the Act.

Chapter 7 of the BCIIP Act gives the ABC Commissioner the power to issue 'examination notices', subject to administrative oversight. BCIIP Act s 61B provides that an examination

3 See A Stewart, A Forsyth, M Irving, R Johnstone and S McCrystal, Creighton and Stewart's Labour Law, $6^{\text {th }}$ ed, Federation Press, Sydney, 2016, ch 27.

4 See CFMEU v BHP Coal Pty Ltd (2014) 253 CLR 243 at [58] where the High Court characterised a peaceful picket as a 'lawful protest'. 


\section{AUSTRALIA}

notice may require a person to give information to the $A B C$ Commissioner; produce documents to the $\mathrm{ABC}$ Commissioner; or attend before the $\mathrm{ABC}$ Commissioner and answer questions relevant to the investigation being undertaken by the Commissioner.

Under s 62, a person commits an offence if they fail to give the information or produce the document as required; attend to answer questions; take an oath or affirmation as requested; or to answer questions put to them in examination. The only defence is that the information requested is the subject of legal professional privilege or is protected by public interest immunity. It is not a defence if answering a question would have the tendency to incriminate the person required to give the answer.

While there are safeguards built into the BCIIP Act in respect of the ABC Commissioner's ability to exercise their coercive powers of examination, this does not alter the fact that the legislation gives the Commissioner extraordinary powers of interrogation of building industry participants that are not general features of the criminal law - including the power to require a person to give evidence which might have the tendency to incriminate themselves. This occurs against the backdrop of other provisions of the Act which make taking strike action in this industry a much riskier proposition than in other industries because if the workers get it wrong (something which is entirely possible under the complicated FW Act regime ${ }^{5}$ ), this will have the effect of making them in breach of the BCIIP Act. Further, the ability of industry participants to act to protect job security and terms of conditions of employment has been substantially undermined through project agreements being rendered unenforceable.

The findings of two Royal Commissions in Australia have demonstrated that there is unlawful conduct in the Australian building and construction industry. However, there is already a complex and sophisticated regulatory system in place through the FW Act, and the enforcement agency responsible for that Act. The need for this special and coercive legislation is debateable. The fact that this legislation is anti-worker and breaches fundamental principles of freedom of association and the privilege against self-incrimination is undeniable.

5 See for example, Creighton, B., McCrystal, S. (2017) 'Esso Australia Pty Ltd v The Australian Workers' Union: Breaches of Orders, Coercion and Protected Industrial Action under the Fair Work Act 2009 (Cth)' 39(3) Sydney Law Review, forthcoming. 